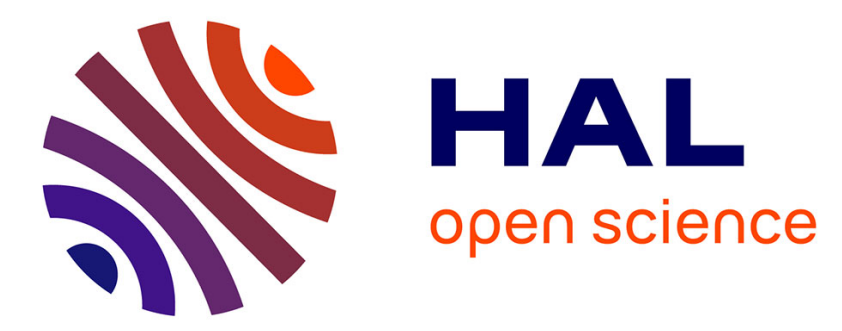

\title{
Segregation of wood particles in a bubbling fluidized bed
} Benjamin Cluet, Guillain Mauviel, Yann Rogaume, Olivier Authier, Arnaud Delebarre

\section{To cite this version:}

Benjamin Cluet, Guillain Mauviel, Yann Rogaume, Olivier Authier, Arnaud Delebarre. Segregation of wood particles in a bubbling fluidized bed. Fuel Processing Technology, 2015, 133, pp.80-88. 10.1016/j.fuproc.2014.12.045 . hal-01250404

\section{HAL Id: hal-01250404 \\ https://hal.science/hal-01250404}

Submitted on 5 Jan 2016

HAL is a multi-disciplinary open access archive for the deposit and dissemination of scientific research documents, whether they are published or not. The documents may come from teaching and research institutions in France or abroad, or from public or private research centers.
L'archive ouverte pluridisciplinaire HAL, est destinée au dépôt et à la diffusion de documents scientifiques de niveau recherche, publiés ou non, émanant des établissements d'enseignement et de recherche français ou étrangers, des laboratoires publics ou privés.

\section{(이) $\$$}

Distributed under a Creative Commons Attribution - NonCommercial - NoDerivatives| 4.0 


\section{Segregation of wood particles in a bubbling fluidized bed}

2

3

4

\section{$9 \quad \underline{\text { Abstract }}$}

Understanding wood segregation in bubbling fluidized beds is of importance for the global analysis, comprehensive modeling, and scale-up of bubbling fluidized bed biomass gasifiers. This study presents measurements of voidage and segregation taken during experiments in

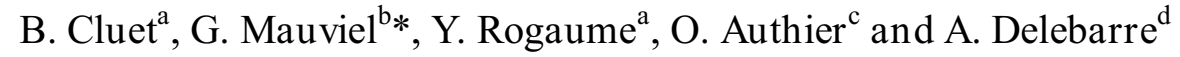 \\ ${ }^{a}$ LERMAB, Université de Lorraine, 27 rue Philippe Séguin; 88051 Epinal, France \\ b* LRGP, CNRS, Université de Lorraine, 1 rue Granville, 54000 Nancy, France \\ ${ }^{\mathrm{c}}$ EDF R\&D, 6 Quai Watier, 78400 Chatou, France
}

${ }^{\text {d }}$ LEMTA, CNRS, Université de Lorraine, 2 av. de la Forêt de Haye, 54504 Vandoeuvre les

Nancy, France fluidized beds containing inert materials mixed with biomass particles. The features of the wood particles affect the bed axial homogeneity; a small particle size or a high density increases homogeneity. When gas velocity is low, the biomass particles are more segregated from olivine compared to the results achieved with larger velocities. In all experiments, a significant portion of the wood remains within the bed (50-80\%), while the rest of the biomass floats at the bed surface. The experimental modeling accurately represents the voidage of the bed, with the exception of the upper part of the bed and the floating portion of the biomass particles. The results of the present study are in agreement with recent publications. 
22 Fluidization, segregation, biomass, wood, mixing, voidage, pressure analysis

23

\section{Introduction}

The gasification or combustion of wood chips in fluidized beds necessitates the use of an inert bed material in which wood particles are introduced. These mixtures of inert materials with "wood/char" particles have complex fluidization behaviors. For instance, Delebarre et al. [1] pointed out that the minimum fluidization velocity concept is not straightforward for these type of binary mixtures.

Understanding wood segregation in bubbling fluidized beds remains important for the global analysis, comprehensive modeling, and scale-up of bubbling fluidized bed gasifiers [2]. This phenomenon is strongly coupled with wood thermochemical reactions (pyrolysis and gasification) and bed hydrodynamics [3]. Segregation is likely to occur when there is a large difference in drag per unit weight between different solid particles.

The segregation of thick wood samples such as chips or pellets in sand beds has been less studied compared to pyrolysis/gasification/combustion kinetics [4-15] or fluidized bed hydrodynamics $[1,3,16-21]$. Some studies conducted on solid mixing in fluidized beds have focused on particles with the same density but different shapes or diameters [22-24] or particles with the same shape but different densities [22].

Norouzi et al. [25] studied the solid mixing pattern in a bubbling fluidized bed using a radioactive tracer with the same density as the bed material. This radioactive particle tracking method for visualizing the fluidized bed interior is an efficient technique, although it involves complex materials. Recently, Fotovat et al. [26] used the same experimental setup to analyze wood distribution in a sand fluidized bed; measurements were taken with a single tracer particle. 
44 They found a wood distribution all along the bed (Figure 9) and better gas mixing with increasing velocity.

Wirsum et al. [27] studied light and large particles in sand using a magnetic field to track particles. Vertical mixing was improved by smaller and denser flotsams along with small sand particle diameters and high superficial velocities. Zhang et al. [28] investigated wood segregation and mixing in a fluidized bed. The results were based on three-layer sampling in a bed with a height of $300 \mathrm{~mm}$. They also found that gas velocity affects segregation. In the regime of steady fluidization, mixing and segregation compete with each other, and there is a gas velocity that produces the maximum mixing for any given mixture.

Bruni et al. [29] studied the segregation of biomass particles in an incipient bubbling fluidized bed. Biomass particles tend to segregate at the upper part of bed due to endogenous bubbles generated by devolatilization.

Some studies have been conducted on lateral mixing in fluidized beds [30-32]. Olsson et al. [31] investigated wood and sand mixing, demonstrating that lateral dispersion is strongly dependent on bubble path. Wood concentration is more significant between bubble paths, and lateral dispersion is higher in the middle part of the bed than close to the surface. In addition, lateral dispersion is lower than vertical dispersion [30].

Segregation has often been quantitatively evaluated by a coefficient of segregation or a mixing index. The mixing index is defined by the ratio of the jetsam (i.e., solids that occupy the bottom of the bed) concentration in the upper layer to the average jetsam concentration [33]. Experimental evidence $[34,35]$ has shown that the solid composition along the bed is generally not uniquely represented by this ratio. Hemati et al. [34] suggested using a relationship based on the integration of the concentration profile along the bed. 
The aim of this work is to present an experimental study on axial segregation of thick wood in a relatively large lab-scale bubbling fluidized bed (i.e., diameter of $242 \mathrm{~mm}$ ) to limit the wall effect (the ratio of the particle equivalent spherical diameter to the bed diameter is at least equal to 18). As discussed below, some similar experimental studies have already been performed, but previous results were obtained mainly using single particle tracking or thick layer sampling. This study is based on simple pressure analyses and local bed sampling with 50-mm-thick layers. The effects of several parameters related to wood particles are also studied (i.e., size, shape and density). Endogenous bubble formation is not studied herein, even though this phenomenon could impact segregation in real fluidized bed gasifiers.

2. Materials, methods and calculation

77 2.1. Materials

\subsubsection{Experimental device}

Experiments were carried out in a cold cylindrical fluidized bed composed of five parts: (i) an inlet gas system, (ii) a gas distributor, (iii) a fluidized bed column, (iv) a wood injection system and (v) a data acquisition system. A schematic representation of the experimental setup is given in the Supplementary Material (Figure 1).

The fluidized bed was a cylindrical PMMA vessel with an inner diameter of $242 \mathrm{~mm}$, a height of $2.5 \mathrm{~m}$, and a thickness of $8 \mathrm{~mm}$. This vessel was drilled on a vertical line each $50 \mathrm{~mm}$ to create pressure transducer inlets. The first hole was drilled $13 \mathrm{~mm}$ from the air distributor. Stainless steel pipe (8-mm external diameters, 3-mm internal diameters, and 40-mm lengths) were placed in each of these holes. To prevent bed leakage, filters were inserted in all of the pipes.

A PMMA distributor plate with a diameter of $242 \mathrm{~mm}$ and a height of $10 \mathrm{~mm}$ was perforated by 230 holes with diameters of $2.5 \mathrm{~mm}$ arranged in a square pitch in order to uniformly distribute the fluidization gas and avoid channeling and/or slugging. A cloth filter was placed over the air 
91 distributor plate to prevent the inert bed particles from falling down. The pressure drop of the air 92 distributor was approximately $2500 \mathrm{~Pa}$ at $0.3 \mathrm{~m} / \mathrm{s}$.

93 An air box was included between the blower and the distributor plate to homogenize the air 94 flow and obtain good fluidization. This plenum was a cylindrical PMMA vessel with an inner 95 diameter of $242 \mathrm{~mm}$ and a height of $510 \mathrm{~mm}$ divided by a plate perforated by 5 -mm holes. On 96 the upper part of this plate, a layer of stainless steel marbles (15-mm diameter) was employed to 97 homogenize air flow (Supplementary Material Figure 1).

98 The feeding gas was supplied by a side channel blower (MPR, $2.2 \mathrm{~kW}, 2900 \mathrm{rpm}$ ). The blower 99 velocity was controlled by a variable frequency drive (Leroy Somer FMV2304). The velocity of 100 the gas was measured by a hot wire anemometer $(0-30 \mathrm{~m} / \mathrm{s})$ coupled to a computer for 101 acquisition. The experimental setup was run between $0.04 \mathrm{~m} / \mathrm{s}$ and $0.55 \mathrm{~m} / \mathrm{s}$; this velocity is 102 equivalent to $0.3-6.8$ of the minimum fluidization velocity $\left(\mathrm{U}_{\mathrm{mf}}\right)$ depending on the olivine 103 properties.

104 As shown in Figure 1 of the Supplementary Material, the bed was divided into 50-mm-thick 105 layers delimited by pressure pipes. The pressure acquisition system was composed of eight 106 pressure transducers (Honeywell ascx $0-5 \mathrm{dn}$ and ascx $0-1 \mathrm{dn}$ ) connected to a USB data acquisition 107 device (NI USB-6009). The employed transducers were differential pressure sensors; one input 108 was connected to the bed, while the second input was opened and thus was at ambient pressure.

\subsubsection{Bed material}

110 The inert bed material used in all experiments was composed of non-ferrous olivine (supplied 111 by Sibelco Company North Cape Mineral, Norway). The olivine density and other characteristics 112 are summarized in Table 1. Two types of olivine were used in this study: coarse olivine, which 113 was sieved between $0.25 \mathrm{~mm}$ and $0.75 \mathrm{~mm}$ before each experiment, and fine olivine, which was 
passed through $0.25-\mathrm{mm}$ mesh. The fine olivine fraction was fluidized at high velocity $\left(>7 \mathrm{U}_{\mathrm{mf}}\right)$

115 to remove the very fine particles.

116 These particle fractions are the same as those used in hot gasifiers. Using the same particles in a 117 cold fluidized bed implies the failure to comply with the scale-up criteria proposed by Glicksman 118 et al. [36]. However, as mentioned by Leckner et al. [37], it is not a simple task to find perfectly 119 suitable particles to meet these criteria.

120 The olivine particle size distribution (Supplementary Material Figure 3) was measured by laser 121 light scattering with a Malvern Mastersizer Hydro 2000 analyzer. The results obtained from this 122 method were confirmed by comparison with microscope image analysis. These olivine particles 123 were classified as Geldart type B because their size and density ranges were within 40-500 $\mu \mathrm{m}$ 124 and $1400-4500 \mathrm{~kg} / \mathrm{m}^{3}$, respectively. Olivine sphericity was obtained from the image analysis of 125 approximately 400 particles for each type of olivine. For each particle, three diameters were measured: (i) $d_{\min }$, the smallest dimension of particle; (ii) $d_{\max }$, the largest dimension of particle;

127 and (iii) $d_{\text {mean }}$, the mean diameter of particle. Two ratios, $\frac{d_{\text {mean }}}{d_{\text {max }}}$ and $\frac{d_{\min }}{d_{\text {mean }}}$, were calculated and 128 are drawn on the Zingg diagram [38] modified by Lees [39] (Supplementary Material Figure 2).

$$
\text { 2.1.3. Wood }
$$

130 Two types of wood were used in the segregation experiments: beech wood $\left(685 \mathrm{~kg} / \mathrm{m}^{3}\right)$, a 131 typical wood for bioenergy applications, and balsa wood $\left(190 \mathrm{~kg} / \mathrm{m}^{3}\right)$, which has approximately 132 the same density as char from beech wood. The advantage of balsa wood is that it is not friable 133 compared to wood char.

134 Two particles shapes were selected for the experiments: cylindrical shape (dowels), with a 135 sphericity equal to 0.77 , and chip-like shape, with a sphericity equal to 0.50 . These two shapes 136 were chosen to assess the effect of particle shape on segregation. For balsa particles, two sizes 
138 Table 2 and Figure 1.

139

140 Three geometrical characteristics (equivalent spherical diameter $\left(d_{v}\right)$, sphericity $\left(\Phi_{s}\right)$, and

141 effective diameter $\left(d_{\boldsymbol{e} f f}\right)$ ) were calculated from the particle dimensions using Eqs. (1), (2), and

142 (3), respectively.

$$
\begin{gathered}
d_{v}=2 *\left(\frac{3 \pi V_{\text {particle }}}{4}\right)^{\frac{1}{3}} \\
\Phi_{s}=\frac{\pi d_{v}^{2}}{S_{\text {particle }}} \\
d_{\text {eff }}=d_{v} \Phi_{s}
\end{gathered}
$$

143 The wood minimum fluidization velocity was calculated using the correlation of Chitester et al.

144 [40] (Appendix 1).

$145 \quad$ 2.2. Experimental method

146 The experimental setup was run for approximately $30 \mathrm{~min}$ with olivine in order to rearrange 147 the bed structure from fixed bed to steady fluidized bed. During this period, the temperature 148 increased slowly inside the bed due to blower air friction, reaching a final temperature of 149 approximately $25^{\circ} \mathrm{C}$. The measurements were taken when steady state was achieved.

150 2.2.1. Minimum fluidization velocity

151 The minimum fluidization velocity is the smallest superficial gas velocity at which the 152 pressure drop is equal to the bed weight per unit surface area. An olivine bed with a height of $153265 \mathrm{~mm}(20.9 \mathrm{~kg})$ was used to measure the minimum fluidization velocity. After fluidizing the 154 bed vigorously at a high superficial gas velocity (approximately $3.5 \mathrm{U}_{\mathrm{mf}}$ for coarse olivine and 
6.5 $\mathrm{U}_{\mathrm{mf}}$ for fine olivine), the total pressure drop was measured with "P transducer \#1" for 156 different velocity values (from $0.4 \mathrm{~m} / \mathrm{s}$ to $0 \mathrm{~m} / \mathrm{s}$ ). To determine $U_{\mathrm{mf}}$, a horizontal line 157 corresponding to the average of the high velocity pressure drop was plotted, and a linear fit for 158 low velocity pressure drop was plotted; the intersection of these two lines corresponds to $\mathrm{U}_{\mathrm{mf}}$ 159 (Supplementary Material Figure 4). This velocity was determined only for the olivine bed. In this 160 study, olivine $\mathrm{U}_{\mathrm{mf}}$ is used as a reference to characterize inlet gas velocity.

\subsubsection{Voidage}

162 The voidage is the fraction of gas in a bed. This parameter can be defined for the entire bed or 163 for a layer " $i$ " in the bed (Eq. (4)).

$$
\epsilon_{i}=\frac{V_{g, i}}{V_{i}}
$$

164

165 Two technics were used to calculate voidage: one technique for the bed of olivine without wood, 166 and a second for the bed of olivine with wood.

167 Olivine without wood

168 Voidage was calculated from the pressure data (Eq. (5)).

$$
\epsilon_{\mathrm{i}}=1-\left(\frac{\frac{\Delta P_{i}}{g \cdot h_{i}}}{\rho_{o l}}\right)
$$

169 The voidage calculation requires that two parameters be known: the thickness of each layer and

170 the olivine density. This calculation was performed for all layers except the upper one because its

171 thickness was unknown. 
173 The first experimental method is valid only for a single-component bed. For a binary mixture, 174 the repartition of each type of solid is necessary to determine the voidage. This experiment is 175 divided into two steps. In the first step, the mixture was fluidized for $10 \mathrm{~min}$, and the pressure 176 and velocity were then recorded. The bed expanded slightly during fluidization due to the 177 increase in voidage from the initial voidage to the minimum fluidization voidage. The average 178 bed height during fluidization was $h_{b, f}$. At the end of this step, the air supply was shut down 179 suddenly $(0.5 \mathrm{~s})$, and the bed fell down without the rearrangement of particles. The bed height 180 was then equal to the fixed state bed height $\left(h_{b, s}\right)$.

181 The second experimental step involved the sampling and sieving of each layer in bed. The data 182 were then compared between the fluidization results and the sampling results. It is necessary to 183 calculate an expansion factor $f_{\exp }$ (Eq. (6)) that represents the height evolution between the fixed 184 and fluidized states. To compare the results from solid sampling and pressure analysis, it is 185 necessary to extrapolate the sampling data from the height at a fixed state $\left(h_{b, s}\right)$ to the fluidized 186 height $\left(h_{b, f}\right)$. This extrapolation induces the assumption that the layer characteristics are 187 identical.

$$
f_{\text {exp }}=\frac{h_{b, f}}{h_{b, s}}
$$

188 This analysis enables the determination of the evolution of the wood fraction in the fluidized bed.

189 All calculations are summarized as follows. The voidage of each layer was calculated by Eq. (7).

$$
\epsilon_{i}=1-\frac{\rho_{a p p, i}}{\rho_{o l}} \cdot\left(1-\omega_{i} \cdot\left(1-\frac{\rho_{o l}}{\rho_{w}}\right)\right)
$$

190 Several parameters are needed for this calculation; the local wood mass fraction $\omega_{i}$ can be

191 deduced using wood mass sampling data for each layer (Eq. (8)). 


$$
\omega_{i}=\frac{m_{i, w}}{m_{i}}
$$

192 The wood mass fraction must be calculated for each layer. The height of the layer during sieving 193 is the standstill height and not the fluidized height; to account for this discrepancy, the height of 194 sieving is corrected with $f_{\exp }$ (Eq. (9)).

$$
h_{i, f}=f_{\exp } h_{i, s}
$$

195 The apparent density $\rho_{a p p}$ of each layer was calculated from the determined pressures using Eq. 196 (10).

$$
\rho_{a p p, i}=\frac{\Delta \mathrm{P}_{\mathrm{i}}}{\mathrm{gh}_{i, f}}
$$

197

198

199

200

201

202

203

(Eq. (12)).

$$
I D M_{i}=\frac{\omega_{i}}{\bar{\omega}}
$$

204 The index IDM was used to calculate the global mixing index M (Eq (13)) [42], where $\mathrm{N}$ is the 205 total number of layers in the bed. In this study, the M index was below "1" (perfectly mixed bed) 206 and could have negative values (highly segregated bed).

$$
M=1-\left(\bar{\omega} \frac{\sum_{i=1}^{N}\left(I D M_{i}-1\right)^{2}}{N(1-\bar{\omega})}\right)^{0.5}
$$


This ratio is strongly dependent of the choice of layer thickness. To limit the effect of this choice and obtain an index that varies between 0 and $100 \%$, a new index $\left(\mathrm{H}_{\text {moy }}\right)$ was defined as the average height of wood in the bed divided by the fluidized bed height (Eq.(14)):

$$
H_{m o y}=\frac{\sum_{i} V_{w, i} \bar{h}_{i}}{V_{w} h_{b, f}} * 100
$$

210 If wood is totally segregated to the bed surface, $\mathrm{H}_{\text {moy }}$ tends to $100 \%$, while $\mathrm{H}_{\text {moy }}$ tends to $0 \%$ if

211 the wood is totally segregated near the distributor. If the bed is well mixed, $\mathrm{H}_{\text {moy }}=50 \%$;

212 however, if $\mathrm{H}_{\text {moy }}=50 \%$, the bed is not necessarily well mixed. For instance, the segregation of

213 wood particles in the middle of the bed would also lead to $\mathrm{H}_{\text {moy }}=50 \%$.

214 3. Results and discussion

215 The employed operating conditions are summarized in Table 3. For olivine/wood mixtures, the 216 global volume ratio was generally equal to $0.075 \mathrm{~m}_{\text {wood }}^{3} / \mathrm{m}_{\text {wood+olivine. According to Fotovat et }}^{3}$ 217 al. [26], the influence of the global volume ratio on segregation is actually quite low.

\section{3.1. Minimum fluidization velocity}

219 The measured $U_{m f}$ is equal to $0.137 \mathrm{~m} / \mathrm{s}$ for coarse olivine and $0.082 \mathrm{~m} / \mathrm{s}$ for fine olivine 220 (Supplementary Material Figure 4). These $\mathrm{U}_{\mathrm{mf}}$ values correspond to mean diameters $\left(\mathrm{d}_{\mathrm{v}}\right)$ of $221373 \mu \mathrm{m}$ for coarse olivine and $233 \mu \mathrm{m}$ for fine olivine calculated by the correlation of Chitester 222 et al. [40] (Appendix 1). These values are very close to the mean diameters measured by 223 Malvern analysis (Table 1).

\section{3.2. Voidage}

225 As explained in section 2.2.2, an expansion factor was calculated from the fixed bed height 226 determination and from the fluidized bed height obtained by pressure measurements. For low 227 velocities (less than $3.15 \mathrm{U}_{\mathrm{mf}}$ ), the expansion factor $f_{\text {exp }}$ was approximately 1.22 regardless of 
228 the experimental features. For higher velocities, $f_{\exp }$ was approximately 1.25 . This variance in

$229 f_{\text {exp }}$ is not significant, which make sense because the olivine particles are classified in Geldart

230 group B. Because $f_{\text {exp }}$ was quite constant, the global voidage of the bed was also quite constant;

231 however, it is interesting to take a closer look at the local voidage along the bed, which was not

232 uniform.

233 Olivine without wood

234 Figures 2 and 3 show the voidage profiles of the deep and shallow beds of coarse olivine and 235 the shallow bed of fine olivine. For these three series of experiments for olivine without wood, 236 the bottom part (0-60\%) of the bed was less porous than the upper part. The highest voidage was 237 found for the layer just below the surface. For fine olivine, the voidage was less variable along 238 the bed height, with a minimum voidage of 0.54 and a maximum voidage of 0.59 .

239 Olivine and wood mixture

240 The voidage profiles of olivine and wood mixtures were derived from Eqs. (7)-(10). Figure 2 241 presents the profiles for different mixtures of coarse olivine and wood, indicating that no 242 difference in voidage was observed among all experiments.

243 The voidage trend observed for fine olivine was very different (Figure 3); the voidage 244 decreased with height and was below $60 \%$ in the top layer, whereas the voidage exceeded $65 \%$ 245 for coarse olivine in the same layer. At $2.15 \mathrm{U}_{\mathrm{mf}}$, the presence of balsa chips affects bed voidage, 246 especially in the upper layer.

247 Figures 2 and 3 also compare the modeling and experimental results. The experimental 248 voidage results differ from the modeling estimates (Appendix 1), which indicate a continuous 249 decrease in voidage with height due to increasing bubble size. 
For coarse olivine (Figure 2), the employed correlations are quite good for predicting the 251 voidage at the bottom part of the bed (0-50\%); however, in the upper part, the voidage is underestimated. This may be due to bubble splitting near the splash zone, which is not accounted 253 for by the relationships used to estimate voidage. For fine olivine (Figure 3), the prediction is 254 quite good for the bottom part of the bed, where voidage is high; however, the voidage is underestimated all along the bed.

Fotovat et al. [43] demonstrated that the accumulation of biomass particles in the top layers of

257 the bed causes the bubbles to break, whereas the voidage of the emulsion phase significantly

258 deviates from the $\epsilon_{m f}$ of olivine due to the abundance of biomass particles in the top half of the 259 bed. Our experiments confirmed these results and showed that the "bubble breakage" 260 phenomenon seems to also occur for olivine alone.

\subsection{Segregation}

The first set of experiments was carried out using a shallow bed of coarse olivine 263 $\left(\mathrm{h}_{\mathrm{b}, \mathrm{s}}=265 \mathrm{~mm}\right)$ with four different types of wood and two gas velocities $\left(2.15 \mathrm{U}_{\mathrm{mf}}\right.$ and $\left.3.35 \mathrm{U}_{\mathrm{mf}}\right)$.

264 The second set of experiments was performed using a deep bed of coarse olivine $\left(h_{b, s}=391 \mathrm{~mm}\right)$ 265 with beech dowels. The third set of experiments was performed with a shallow bed of fine 266 olivine $\left(h_{b, s}=265 \mathrm{~mm}\right)$ with different velocities and wood shapes. These experiments were 267 performed in order to compare the effects of different features on segregation. To compare the 268 results of the different experiments, $\mathrm{H}_{\text {moy }}$ was calculated for each experiment (Eq.(14)).

\section{Effect of bed height}

270 The beds were mixtures of coarse olivine and beech dowels with global volume ratios of 0.075 $271 \mathrm{~m}_{\text {wood }}^{3} / \mathrm{m}_{\text {wood }+ \text { olivine }}^{3}$ for the shallow bed and $0.099 \mathrm{~m}_{\text {wood }}^{3} / \mathrm{m}_{\text {wood }+ \text { olivine }}^{3}$ for the deep bed. 272 Because of this slight difference, it is preferred to compute the layer wood ratio profiles (Figure 
273 4). No major difference in segregation was observed between the two bed heights. $\mathrm{H}_{\text {moy }}$ differs 274 slightly between the two experiments ( $64 \%$ for the shallow bed and $73 \%$ for the deep bed).

275 Wood was present all along the bed, with a higher concentration in the upper part and very few 276 particles close to the gas distributor.

277 Effect of wood shape

278 For shape experiments, the bed was composed of coarse olivine (initial bed height $=265 \mathrm{~mm}$, 279 velocity $=2.15 \mathrm{U}_{\mathrm{mf}}$ ). Figure 5 shows that the mixing was slightly better for the beech chips $280\left(\mathrm{H}_{\text {moy }}=66 \%\right)$ than for the beech dowels $\left(\mathrm{H}_{\text {moy }}=73 \%\right)$. This phenomenon could be explained by 281 the elongated shape of the chips, which allows them to assume vertical positions and sink into 282 the bed.

\section{Effects of wood density}

284 Figure 6 shows the effects of gas velocity and wood density on the segregation for coarse 285 olivine. Two types of wood (balsa, $159 \mathrm{~kg} / \mathrm{m}^{3}$ and beech, $\left.685 \mathrm{~kg} / \mathrm{m}^{3}\right)$ and two velocities $(2.15$ 286 and $3.35 \mathrm{U}_{\mathrm{mf}}$ ) were employed. At the low velocity, higher density improved mixing : $\mathrm{H}_{\text {moy }}$ for 287 beech wood at low velocity was $66 \%$, while that of balsa was $85 \%$. For the higher velocity, 288 density had only a minor effect on segregation phenomena : $\mathrm{H}_{\text {moy }}$ was $68 \%$ for beech wood and $28975 \%$ for balsa wood. In all cases, the mixing was better for beech particles. The "well mixed 290 line” drawn in Figure 6 represents a constant wood volume fraction $\left(\mathrm{H}_{\text {moy }}=50 \%\right)$.

291 Effect of wood size

292 Coarse olivine and balsa were used to study the effect of wood size on mixing (Figure 7). Two 293 velocities were used for each particle size. As previously discussed, the higher velocity resulted 294 in better mixing for the large balsa chips : at the low velocity, $\mathrm{H}_{\text {moy }}$ was $85 \%$, while it was $75 \%$ at the high velocity. For small balsa chips, better mixing was also observed at the higher velocity 
: $\mathrm{H}_{\text {moy }}$ was $72 \%$ at the low velocity, while it was $64 \%$ at the high velocity. Size had an effect on segregation : a small wood size improved mixing.

The influence of velocity was already shown in Figures 6 and 7. However, in those experiments, the maximum velocity was quite low (3.35 $\left.\mathrm{U}_{\mathrm{mf}}\right)$. To further study the effect of velocity on mixing, fine olivine and beech dowels were investigated at three velocities : 2.7, 5 , and $6.48 \mathrm{U}_{\mathrm{mf}}$ (Figure 8$)$. At the low velocity $\left(2.7 \mathrm{U}_{\mathrm{mf}}\right), \mathrm{H}_{\text {moy }}$ was $81 \%$, while it was $63 \%$ at the medium velocity $\left(5 \mathrm{U}_{\mathrm{mf}}\right)$ and $61 \%$ at the high velocity $\left(6.48 \mathrm{U}_{\mathrm{mf}}\right)$. Thus, mixing is increased greatly with increasing velocity.

All $\mathrm{H}_{\text {moy }}$ values and their corresponding experimental operating conditions are summarized in

Table 3. In all experiments, the partial segregation of wood was observed; a significant mass of wood $(20-50 \%)$ floated at the bed surface, while the other part $(50-80 \%)$ was partially mixed in the bed. The reduction in the difference in density between the solids seems to improve mixing at

310 low velocity (i.e., a reduction in biomass particle density increases particle segregation). At a higher velocity, the effect of density seems less important. A smaller wood size also improves mixing. Figure 9 shows that these results are close to those obtained by Fotovat et al. (Table 4)

313 [26] using similar experimental conditions (approximately $3 \mathrm{U}_{\mathrm{mf}}$ ). The main differences are observed in the upper part of bed; this could be explained by the fact that the wood volume

315 fraction is slightly higher in our study $\left(0.034 \mathrm{~m}^{3}{ }_{\text {wood }} / \mathrm{m}^{3}\right.$ bed $)$. The effect of fluidization velocity is 316 less important in our study than in that of Fotovat et al; however, the velocity range is also 317 different.

\section{4. $\underline{\text { Conclusion }}$}


This study presents the results of voidage and segregation experiments in fluidized beds of inert materials and wood particles. Two types of inert materials (fine and coarse olivine) with two different minimum fluidization velocities were employed. For the same superficial velocity,

322 the coarse olivine presents a more variable voidage along the height of the bed. These inert

323 materials were then mixed with two types of wood. For the coarse olivine, the presence of wood 324 had no significant effect on the voidage. For fine olivine, the wood affected the voidage, 325 resulting in decreased voidage in the upper part of the bed.

326 The segregation experiments show that the features of the wood affect the axial homogeneity 327 of the mixture: mixing is increased by small particle sphericity and high wood density. The 328 fluidization velocity also affects the mixture: when the velocity was low $\left(<3 \mathrm{U}_{\mathrm{mf}}\right)$, the biomass 329 particles tended to be more segregated than when the velocity was higher than $3 \mathrm{U}_{\mathrm{mf}}$ (except for 330 beech chips in coarse olivine). At $6.5 \mathrm{U}_{\mathrm{mf}}$, the mixing quality was only slightly better than at 5 $331 \mathrm{U}_{\mathrm{mf}}$. In all experiments, an important portion of the wood remained within the bed (50-80\%), 332 while the rest of biomass floated at the bed surface.

333 The voidage of the bottom part of the bed was well represented by usual correlations, while the 334 voidage fraction in the upper part of the bed was underestimated. The results of the present study 335 are in agreement with recently published results in the literature.

\section{ACKNOWLEDGMENTS}

338 The authors acknowledge the financial support of ANR (Agence Nationale de la Recherche) to 339 the GAMECO project that aims to better understand and model biomass gasifiers. 
343 d: diameter (m)

344 IDM : local mixing index

$345 f_{\text {exp }}$ : expansion factor (dimensionless)

$346 g$ : gravitational acceleration $\left(\mathrm{m} \cdot \mathrm{s}^{-2}\right)$

$347 \quad h$ : height $(\mathrm{m})$

$348 \mathrm{H}_{\text {moy: }}$ average biomass normalized height

349 m: mass $(\mathrm{kg})$

350 M: global mixing index (dimensionless)

$351 \Delta P$ : pressure drop $(\mathrm{Pa})$

352 u: velocity $(\mathrm{m} / \mathrm{s})$

$353 \quad \mathrm{~V}$ : volume $\left(\mathrm{m}^{3}\right)$

$354 x$ : wood ratio $\left(\mathrm{m}^{3}\right.$ wood $/ \mathrm{m}^{3}$ wood tot $)$

355

356 Greek symbols

$357 \epsilon$ : voidage (dimensionless)

$358 \mathrm{n}$ : wood volume fraction $\left(\mathrm{m}^{3}\right.$ wood $/ \mathrm{m}^{3}$ wood+olivine $)$

$359 \mathrm{n}$ ': wood volume fraction in Fotovat et al. [26] $\left(\mathrm{m}^{3}\right.$ wood $/ \mathrm{m}^{3}$ layer $)$

$360 \rho$ : density $\left(\mathrm{kg} \cdot \mathrm{m}^{-3}\right)$

$361 \omega$ : wood fraction $\left(\mathrm{kg}_{\text {wood }} / \mathrm{kg}_{\text {layer }}\right)$

$362 \bar{\omega}$ : mean wood fraction $\left(\mathrm{kg}_{\text {wood }} / \mathrm{kg}_{\text {bed }}\right)$

$363 \Phi:$ sphericity (dimensionless)

364

$365 \quad \underline{\text { Subscripts }}$

366 app: apparent 
367 b: bed

368 bubble: bubble

369 eff: effective

370 f: fluidized

371 g: gas

$372 i$ : layer number

373 max: maximum

374 mean: mean

375 min: minimum

376 mf: minimum fluidization

377 ol: olivine

378 p: particle

379 s: standstill

380 tot: total (in the whole bed)

381 v: volume

382 w: wood

383 0: initial

384 
387 Appendix 1: Hydrodynamics correlations

388 Archimedes number

$389 \quad A r=\frac{d p_{o l}^{3} \cdot \rho_{g a s} g\left(\rho_{o l}-\rho_{g a s}\right)}{\mu_{g a s}{ }^{2}}$

390 Minimum fluidization Reynolds number $\left(R e_{m f}\right)$ correlated by Chitester et al. [40]

$391 R e_{m f}=\left((28.7)^{2}+0.0494 . A r\right)^{0.5}-28.7$

392 Minimum fluidization voidage correlated by the Ergun equation [16]

$393 \quad \frac{1.75}{\epsilon_{m f}^{3} \cdot \Phi} \cdot R e_{m f}^{2}+\frac{150\left(1-\epsilon_{m f}\right)}{\epsilon_{m f}^{3} \cdot \Phi^{2}} R e_{m f}=A r$

394 Initial bubble diameter correlated by Mori and Wen[44] $\left(\mathrm{cm} \cdot \mathrm{s}^{-1}\right)$

395

$d_{\text {bubble }}=\frac{2.78}{10^{2} g}\left(\left(u_{g a s}-u_{m f}\right)\right)^{2}$

396 Maximum bubble diameter correlated by Mori and Wen[44] $\left(\mathrm{cm} . \mathrm{s}^{-1}\right)$

397

$$
d_{\text {bubble } \max }=0.652\left(\frac{\pi}{4} d_{\text {bottom }}^{2}\left(u_{\text {gas }}-u_{m f}\right)\right)^{0.4}
$$

398 Bubble diameter at height " $h$ " correlated by Mori and Wen [44] $\left(\mathrm{cm} . \mathrm{s}^{-1}\right)$

$$
d_{\text {bubble }}=d_{\text {bubble } \max }-e^{-\frac{0.3 h}{d_{\text {bed }}}}\left(d_{\text {bubble } \max }-d_{\text {bubble }}\right)
$$


400 Single bubble velocity correlated by Davidson and Harrison [45] $\left(\mathrm{cm} . \mathrm{s}^{-1}\right)$

$401 u_{b r}=0.711\left(g \cdot d_{\text {bubble }}\right)^{0.5}$

402 Bubble velocity correlated by Davidson and Harrison [45] $\left(\mathrm{cm} \cdot \mathrm{s}^{-1}\right)$

$403 \quad u_{\text {bubble }}=u_{b r}+\left(u_{g a s}-u_{m f}\right)$

404 Bubble fraction in the bed with deviation factor (Y) from two-phase theory.

405 frac $_{\text {bubble }}=Y \frac{\left(u_{g a s_{b m}}-u_{m f_{o l}}\right)}{u_{b u b b l e}}$

406 Deviation factor from two-phase theory [46]

$407 Y=2.27 A r^{-0.21}$

408 Emulsion voidage from two-phase theory:

$409 \epsilon_{\text {emulsion }}=\epsilon_{m f}$

410 The average voidage of bed is calculated as follows:

$411 \epsilon=$ frac $_{\text {bubble }}+\left(1-\right.$ frac $\left._{\text {bubble }}\right) \epsilon_{\text {emulsion }}$

412 Appendix 2: Supplementary materials

413 AUTHOR INFORMATION

414 Corresponding Author

$415 *$ *Corresponding author: guillain.mauviel@univ-lorraine.fr. 
417 [1] A.B. Delebarre, A. Pavinato, J.C. Leroy, Fluidization and mixing of solids distributed in size and density, Powder Technol. 80 (1994) 227-233. doi:10.1016/S00325910(94)80007-3.

[2] H. Cui, J.R. Grace, Fluidization of biomass particles: A review of experimental multiphase flow aspects, Chem. Eng. Sci. 62 (2007) 45-55. doi:10.1016/j.ces.2006.08.006.

[3] A. Gomez-Barea, B. Leckner, Modeling of biomass gasification in fluidized bed, Prog. Energy Combust. Sci. 36 (2010) 444-509. doi:10.1016/j.pecs.2009.12.002.

[4] O. Authier, M. Ferrer, G. Mauviel, A.-E. Khalfi, J. Lédé, Wood Fast Pyrolysis: Comparison of Lagrangian and Eulerian Modeling Approaches with Experimental Measurements, Ind Eng Chem Res. 48 (2009) 4796-4809. doi:10.1021/ie801854c.

[5] A. Dufour, P. Girods, E. Masson, Y. Rogaume, A. Zoulalian, Synthesis gas production by biomass pyrolysis: Effect of reactor temperature on product distribution, Int. J. Hydrog. Energy. 34 (2009) 1726-1734. doi:10.1016/j.ijhydene.2008.11.075.

[6] M. Corbetta, A. Frassoldati, H. Bennadji, K. Smith, M.J. Serapiglia, G. Gauthier, et al., Pyrolysis of Centimeter-Scale Woody Biomass Particles: Kinetic Modeling and Experimental Validation, Energy Fuels. 28 (2014) 3884-3898. doi:10.1021/ef500525v.

[7] E. Ranzi, M. Corbetta, F. Manenti, S. Pierucci, Kinetic modeling of the thermal degradation and combustion of biomass, Chem. Eng. Sci. 110 (2014) 2-12. doi:10.1016/j.ces.2013.08.014.

[8] E. Ranzi, A. Cuoci, T. Faravelli, A. Frassoldati, G. Migliavacca, S. Pierucci, et al., Chemical Kinetics of Biomass Pyrolysis, Energy Fuels. 22 (2008) 4292-4300. doi:10.1021/ef800551t.

[9] P. Pepiot, C.J. Dibble, T.D. Foust, Computational Fluid Dynamics Modeling of Biomass Gasification and Pyrolysis, in: American Society, Washington DC, 2010. doi:10.1021/bk2010-1052.ch012.

[10] R. Radmanesh, Y. Courbariaux, J. Chaouki, C. Guy, A unified lumped approach in kinetic modeling of biomass pyrolysis, Fuel. 85 (2006) 1211-1220. doi:10.1016/j.fuel.2005.11.021.

[11] D. Fiaschi, M. Michelini, A two-phase one-dimensional biomass gasification kinetics model, Biomass Bioenergy. 21 (2001) 121-132. doi:10.1016/S0961-9534(01)00018-6.

[12] M. Puig-Arnavat, J.C. Bruno, A. Coronas, Review and analysis of biomass gasification models, 14 (2010) 2841-2851.

[13] F. Scala, R. Chirone, P. Salatino, Combustion and Attrition of Biomass Chars in a Fluidized Bed, Energy Fuels. 20 (2006) 91-102. doi:10.1021/ef050102g.

[14] O. Senneca, Kinetics of pyrolysis, combustion and gasification of three biomass fuels, Fuel Process. Technol. 88 (2007) 87-97. doi:10.1016/j.fuproc.2006.09.002.

[15] F. Scala, P. Salatino, R. Chirone, Fluidized Bed Combustion of a Biomass Char (Robinia pseudoacacia), Energy Fuels. 14 (2000) 781-790. doi:10.1021/ef9901701.

[16] S. Ergun, Fluid flow through packed columns, Chem Eng Prog. 48 (1952) 89.

[17] C. Y. Wen, Y.H. Yu, A generalized method for predicting the minimum fluidization velocity, AIChE J. 12 (1966) 610-612. doi:10.1002/aic.690120343.

[18] K.S. Lim, J.X. Zhu, J.R. Grace, Hydrodynamics of gas-solid fluidization, Int. J. Multiph. Flow. 21, Supplement (1995) 141-193. doi:10.1016/0301-9322(95)00038-Y. 
[19] Q. Wang, W. Yin, B. Zhao, H. Yang, J. Lu, L. Wei, The segregation behaviors of fine coal particles in a coal beneficiation fluidized bed, Fuel Process. Technol. 124 (2014) 2834. doi:10.1016/j.fuproc.2014.02.015.

[20] F. Parveen, S. Josset, C. Briens, F. Berruti, Effect of size and density on agglomerate breakage in a fluidized bed, 231 (2012) 102-111. doi:10.1016/j.powtec.2012.07.055.

[21] T. Baron, C.L. Briens, P. Galtier, M.A. Bergougnou, Verification of models and correlations for bubble properties in fluidized beds, Chem. Eng. Sci. 45 (1990) $2227-$ 2233. doi:10.1016/0009-2509(90)80099-Z.

[22] L.T. Fan, Y. Chang, Mixing of Large Particles in Two Dimensional Gas Fluidized Beds, Can. J. Chem. Eng. 57 (1979) 88-97. doi:10.1002/cjce.5450570114.

[23] K. Yoshida, H. Kameyama, F. Shimizu, Mechanism of particle mixing and segregation in gas fluidised beds, in: Fluidization, Springer US, J.R. Grace and J.M. Matsen, New York, 1980: pp. 389-396.

[24] M.J.V. Goldschmidt, J.M. Link, S. Mellema, J.A.M. Kuipers, Digital image analysis measurements of bed expansion and segregation dynamics in dense gas-fluidised beds, Powder Technol. 138 (2003) 135-159. doi:10.1016/j.powtec.2003.09.003.

[25] H.R. Norouzi, N. Mostoufi, Z. Mansourpour, R. Sotudeh-Gharebagh, J. Chaouki, Characterization of solids mixing patterns in bubbling fluidized beds, IChemE. 89 (2011) 817-826. doi:10.1016/j.cherd.2010.10.014.

[26] F. Fotovat, J. Chaouki, J. Bergthorson, Distribution of large biomass particles in a sandbiomass fluidized bed: Experiments and modeling, AIChE J. 60 (2014) 869-880. doi:10.1002/aic.14337.

[27] M. Wirsum, F. Fett, N. Iwanowa, G. Lukjanow, Particle mixing in bubbling fluidized beds of binary particle systems, Powder Technol. 120 (2001) 63-69. doi:10.1016/S00325910(01)00348-5.

[28] Y. Zhang, B. Jin, W. Zhong, Experimental investigation on mixing and segregation behavior of biomass particle in fluidized bed, Chem. Eng. Process. 48 (2009) 745-754. doi:10.1016/j.cep.2008.09.004.

[29] G. Bruni, R. Solimene, A. Marzocchella, P. Salatino, J. Yates, P. Lettieri, et al., Selfsegregation of high-volatile fuel particles during devolatilization in a fluidized bed reactor, 128 (2002) 11-21.

[30] L. Shen, J. Xiao, F. Niklasson, F. Johnsson, Biomass mixing in a fluidized bed biomass gasifier for hydrogen production, Chem. Eng. Sci. 62 (2007) 636-643. doi: 10.1016/j.ces.2006.09.033.

[31] J. Olsson, D. Pallarès, F. Johnsson, Lateral fuel dispersion in a large-scale bubbling fluidized bed, Chem. Eng. Sci. 74 (2012) 148-159. doi:10.1016/j.ces.2012.02.027.

[32] J.C. Abanades, G.S. Grasa, Modeling the Axial and Lateral Mixing of Solids in Fluidized Beds, Ind. Eng. Chem. Res. 40 (2001) 5656-5665. doi:10.1021/ie0009278.

[33] A.W Nienow, T Chiba, Fluidization of Dissimilar Materials, in: Fluid. 2nd Ed, Academic Press, J.F Davidson, R.Clift and Harrison, London, 1985.

[34] M. Hemati, K. Spieker, C. Laguérie, R. Alvarez, F.A. Riera, Experimental study of sawdust and coal particle mixing in sand or catalyst fluidized beds, Can. J. Chem. Eng. 68 (1990) 768-772. doi:10.1002/cjce.5450680505.

[35] A. Marzocchella, P. Salatino, V.D. Pastena, L. Lirer, Fluidization in Pyroclastic Flow, in: Ninth Eng. Found. Conf. Fluid., Engineering Foundation, Durango, Colorado, 1998: p. $389 / 788$. 
[36] L.R. Glicksman, M.R. Hyre, P.A. Farrell, Dynamic similarity in fluidization, Int. J. Multiph. Flow. 20, Supplement 1 (1994) 331-386. doi:10.1016/0301-9322(94)90077-9.

[37] B. Leckner, P. Szentannai, F. Winter, Scale-up of fluidized-bed combustion: A review, 90 (2011) 2951-2964. doi:10.1016/j.fuel.2011.04.038.

[38] Zingg, Beitrag zur Schotteranalys, Universitaet Zuerich, 1935.

[39] G. Lees, The measurement of particle shape and its influence in engineering materials., J. Br. Granite Whinestone Fed. (1964) 1-22.

[40] D.C. Chitester, R.M. Kornosky, L.-S. Fan, J.P. Danko, Characteristics of fluidization at high pressure, Chem. Eng. Sci. 39 (1984) 253-261. doi:10.1016/0009-2509(84)80025-1.

[41] P.N. Rowe, A.W. Nienow, The mechanism by which particles segregate in gas fluidised beds-binary systems of near-spherical particles, Trans Inst Chem Eng. 50 (1972) 310-323.

[42] A. Michaels, V. Puzinauskas, Evaluation performance characteristics of mecanical mixing processes the dextrose kaolinite water system, Chem. Eng. Prog. 50 (1954) 604-614.

[43] F. Fotovat, J. Chaouki, J. Bergthorson, The effect of biomass particles on the gas distribution and dilute phase characteristics of sand-biomass mixtures fluidized in the bubbling regime, Chem. Eng. Sci. 102 (2013) 129-138. doi:10.1016/j.ces.2013.07.042.

[44] S. Mori, C.Y. Wen, Estimation of bubble diameter in gaseous fluidized beds, AIChE J. 21 (1975) 109-115. doi:10.1002/aic.690210114.

[45] J.F. Davidson, D. Harrison, Fluidized Particles, Cambridge Univ. Press, New York, 1963.

[46] S.Y. Wu, J. Baeyens, Segregation by size difference in gas fluidized beds, Powder Technol. 98 (1998) 139-150. doi:10.1016/S0032-5910(98)00026-6. 
542 Figure 1. Pictures of wood particles

543 Figure 2. Bed voidage axial profiles with coarse olivine $\left(h_{b, s}=265 \mathrm{~mm}\right.$ or $391 \mathrm{~mm}$, gas velocity $=$ $5442.15 \mathrm{U}_{\mathrm{mf}}$, with or without beech dowels)

545 Figure 3 . Bed voidage axial profiles with fine olivine $\left(h_{b, s}=265 \mathrm{~mm}\right.$, gas velocity $=2.7-6.48 \mathrm{U}_{\mathrm{mf}}$, 546 with or without small chips balsa or beech dowels)

547 Figure 4 . The effect of bed height on the segregation profiles $\left(\mathrm{h}_{\mathrm{b}, \mathrm{s}}=265 \mathrm{~mm}\right.$ or $391 \mathrm{~mm}$, coarse 548 olivine, gas velocity $=2.15 \mathrm{U}_{\mathrm{mf}}$, with beech dowels)

549 Figure 5. The effect of wood shape on segregation profiles $\left(\mathrm{h}_{\mathrm{b}, \mathrm{s}}=265 \mathrm{~mm}\right.$, coarse olivine, gas 550 velocity $=2.15 \mathrm{U}_{\mathrm{mf}}$, with beech chips or dowels)

551 Figure 6 . The effects of wood density on segregation profiles $\left(\mathrm{h}_{\mathrm{b}, \mathrm{s}}=265 \mathrm{~mm}\right.$, coarse olivine, gas 552 velocity $=2.15$ or $3.35 \mathrm{U}_{\mathrm{mf}}$, beech or balsa chips)

553 Figure 7. The effect of wood size on segregation profiles $\left(h_{b, s}=265 \mathrm{~mm}\right.$, coarse olivine, gas 554 velocity $=2.15$ or $3.35 \mathrm{U}_{\mathrm{mf}}$, small or large balsa chips)

555 Figure 8. The effect of gas velocity on segregation profiles $\left(\mathrm{h}_{\mathrm{b}, \mathrm{s}}=265 \mathrm{~mm}\right.$, fine olivine, gas 556 velocity $=2.7-6.48 \mathrm{U}_{\mathrm{mf}}$, with beech dowels)

557 Figure 9. Comparison of the segregation profiles from this study with those of Fotovat et al. [28]

558

559 APPENDIX 2

560 Figure 1. Simplified scheme of the experimental setup

561 Figure 2. Olivine sphericity estimated from Zingg [37] and modified by Lees [38] diagram ( $\times$ : 562 fine olivine, + : coarse olivine)

563 Figure 3. Olivine size distribution measured by Malvern analysis

564 Figure 4. Minimum fluidization velocity

565

566 TABLE CAPTION

567 Table 1. Olivine features

568 Table 2. Wood properties

569 Table 3. Summary of experimental conditions and $\mathrm{H}_{\text {moy }}$ values

570 Table 4. Experimental conditions of Fotovat et al. [26]

571

572 


\begin{tabular}{|ccccc|}
\hline Material & $\begin{array}{c}\text { Particle } \\
\text { density } \\
\left(\mathrm{kg} / \mathrm{m}^{3}\right)\end{array}$ & $\begin{array}{c}\text { Diameter } \\
(\mu \mathrm{m})\end{array}$ & Sphericity & $\begin{array}{c}\mathrm{U}_{\mathrm{mf}} \\
(\mathrm{m} / \mathrm{s})\end{array}$ \\
\hline Coarse Olivine & 3250 & 378 & 0.82 & 0.137 \\
\hline Fine Olivine & 3250 & 237 & 0.78 & 0.082 \\
\hline
\end{tabular}




\begin{tabular}{|ccccccc|}
\hline Material & $\begin{array}{c}\text { Density } \\
\left(\mathrm{kg} / \mathrm{m}^{3}\right)\end{array}$ & $\begin{array}{c}\text { Dimension } \\
(\mathrm{mm}) \pm 0.1 \mathrm{~mm}\end{array}$ & Sphericity & $\mathrm{d}_{\mathrm{v}}(\mathrm{m})$ & $\mathrm{d}_{\mathrm{eff}}(\mathrm{m})$ & $\begin{array}{c}\text { Calculated } \\
\mathrm{U}_{\mathrm{mf}} \text { at } 25^{\circ} \mathrm{C} \\
(\mathrm{m} / \mathrm{s})\end{array}$ \\
\hline Beech & 685 & $\begin{array}{c}8(\text { diam. }) \\
\text { Dowels }\end{array}$ & 0.77 & $1.34 .10^{-2}$ & $1.03 .10^{-2}$ & 1.54 \\
\hline Beech & 685 & $\begin{array}{l}5.5 * 4 * 57 \\
\text { Large chips }\end{array}$ & 0.50 & $1.34 .10^{-2}$ & $0.76 .10^{-2}$ & 1.30 \\
\hline Balsa & 159 & $\begin{array}{l}5.5^{*} 4 * 57 \\
\text { Large chips }\end{array}$ & 0.50 & $1.34 .10^{-2}$ & $0.76 .10^{-2}$ & 0.59 \\
\hline Balsa & 159 & $\begin{array}{l}2 * 4 * 29.5 \\
\text { Small chips }\end{array}$ & 0.50 & $0.76 .10^{-2}$ & $0.38 .10^{-2}$ & 0.34 \\
\hline
\end{tabular}




\begin{tabular}{|cccccccc|}
\hline Figure \# & $\mathrm{U} / \mathrm{U}_{\mathrm{mf}}$ & Olivine & $\begin{array}{c}\text { Initial bed } \\
\text { height } \mathrm{h}_{\mathrm{b}, \mathrm{s}} \\
(\mathrm{mm})\end{array}$ & $\begin{array}{c}\text { Wood } \\
\text { species }\end{array}$ & Shape & $\begin{array}{c}\text { Wood volume / } \\
\text { (olivine + wood } \\
\text { volume) }(\%)\end{array}$ & $\mathrm{H}_{\text {moy }}$ \\
\hline 8 & 6.48 & fine & 265 & beech & dowels & 7.5 & $61 \%$ \\
\hline 8 & 5.04 & fine & 265 & beech & dowels & 7.5 & $63 \%$ \\
\hline 4 & 2.15 & coarse & 391 & beech & dowels & 9.9 & $64 \%$ \\
\hline 7 & 3.35 & coarse & 265 & balsa & small chips & 8.7 & $64 \%$ \\
\hline 5,6 & 2.15 & coarse & 265 & beech & chips & 7.5 & $66 \%$ \\
\hline 6 & 3.35 & coarse & 265 & beech & chips & 7.5 & $68 \%$ \\
\hline 7 & 2.15 & coarse & 265 & balsa & small chips & 8.7 & $72 \%$ \\
\hline 4,5 & 2.15 & coarse & 265 & beech & dowels & 7.5 & $73 \%$ \\
\hline 6,7 & 3.35 & coarse & 265 & balsa & chips & 8.7 & $75 \%$ \\
\hline 8 & 2.70 & fine & 265 & beech & dowels & 7.5 & $81 \%$ \\
\hline 6,7 & 2.15 & coarse & 265 & balsa & chips & 8.7 & $85 \%$ \\
\hline
\end{tabular}




\begin{tabular}{|ccccc|}
\hline $\begin{array}{c}\text { Wood volume } \\
\text { ratio } \\
\left(\mathrm{m}^{3}{ }_{\text {wood }} / \mathrm{m}^{3}{ }_{\text {bed }}\right)\end{array}$ & $\begin{array}{c}\text { Wood } \\
\text { density } \\
\left(\mathrm{kg} / \mathrm{m}^{3}\right)\end{array}$ & $\begin{array}{c}\text { Wood dimension } \\
(\mathrm{mm})\end{array}$ & $\begin{array}{c}\text { Sand } \\
\text { density } \\
\left(\mathrm{kg} / \mathrm{m}^{3}\right)\end{array}$ & $\begin{array}{c}\text { Sand } \\
\text { mean } \\
\text { diameter } \\
(\mu \mathrm{m})\end{array}$ \\
\hline $\begin{array}{c}0.0356 \text { and } \\
0.1359\end{array}$ & 824 & $6.35($ diam $) * 12.70$ & 2650 & 380 \\
\hline
\end{tabular}



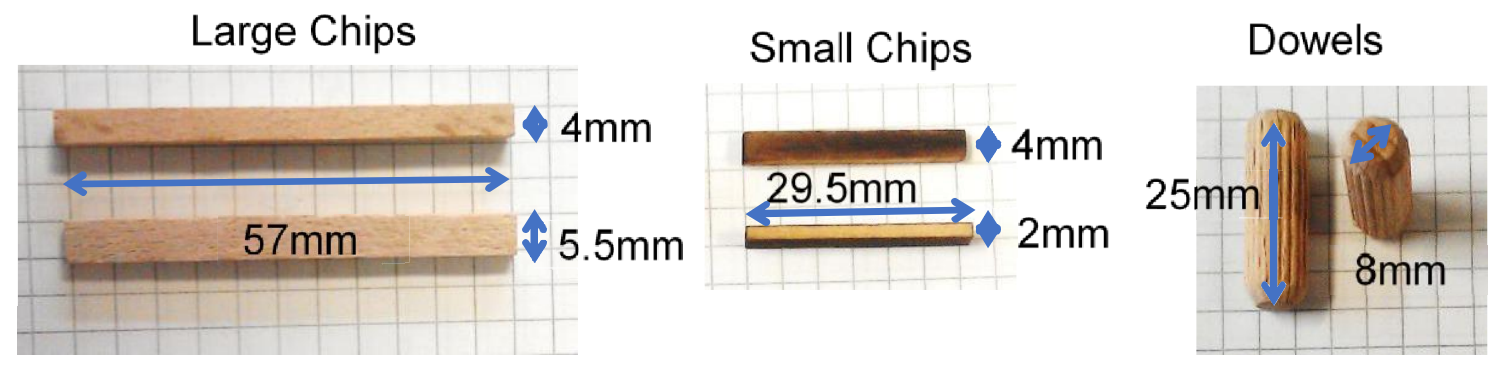


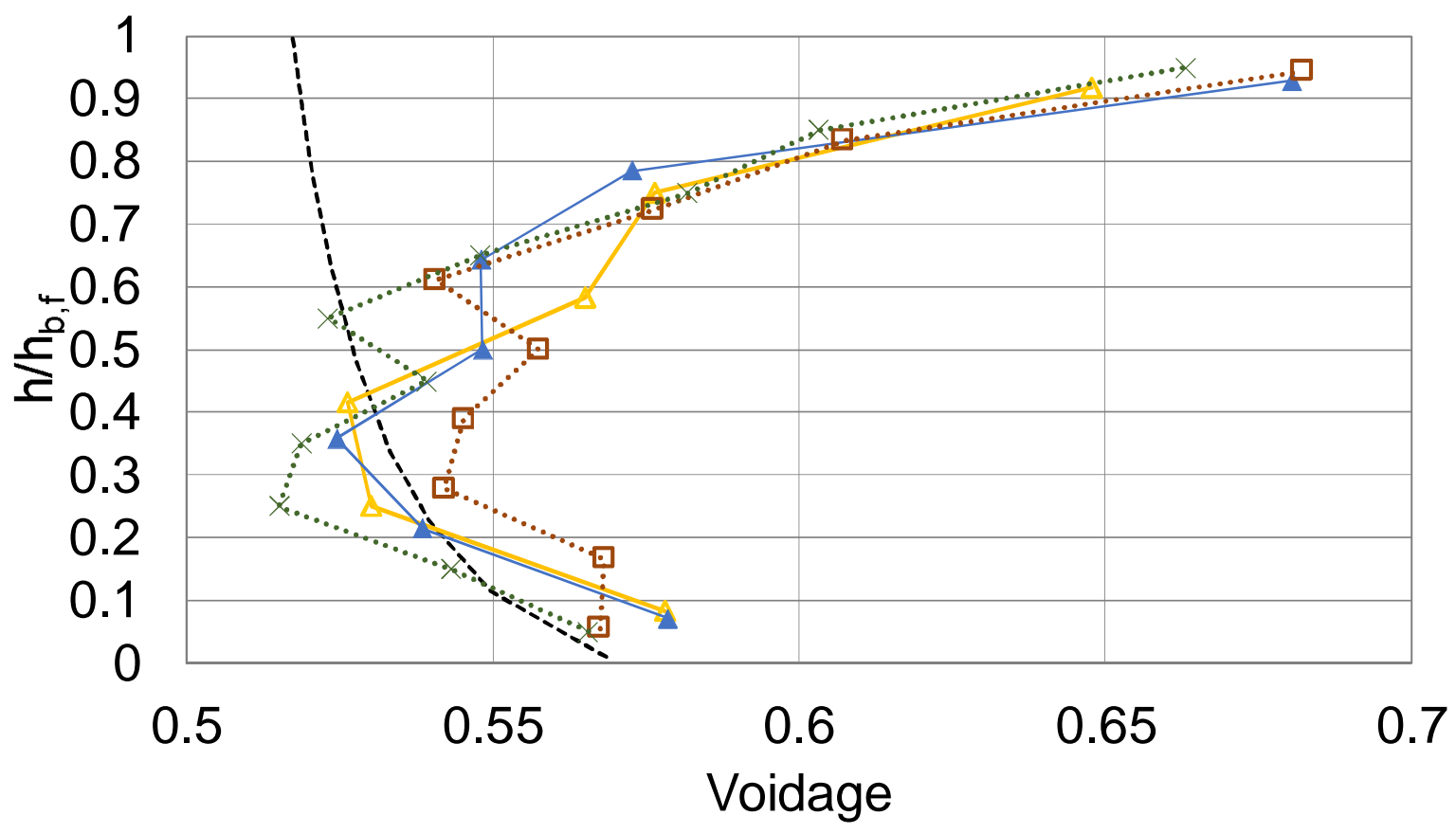

----2.15 Umf, model $\quad \triangle$ shallow bed, no wood

- shallow bed, beech dowels •••-deep bed, no wood

..*x*. deep bed, beech dowels 


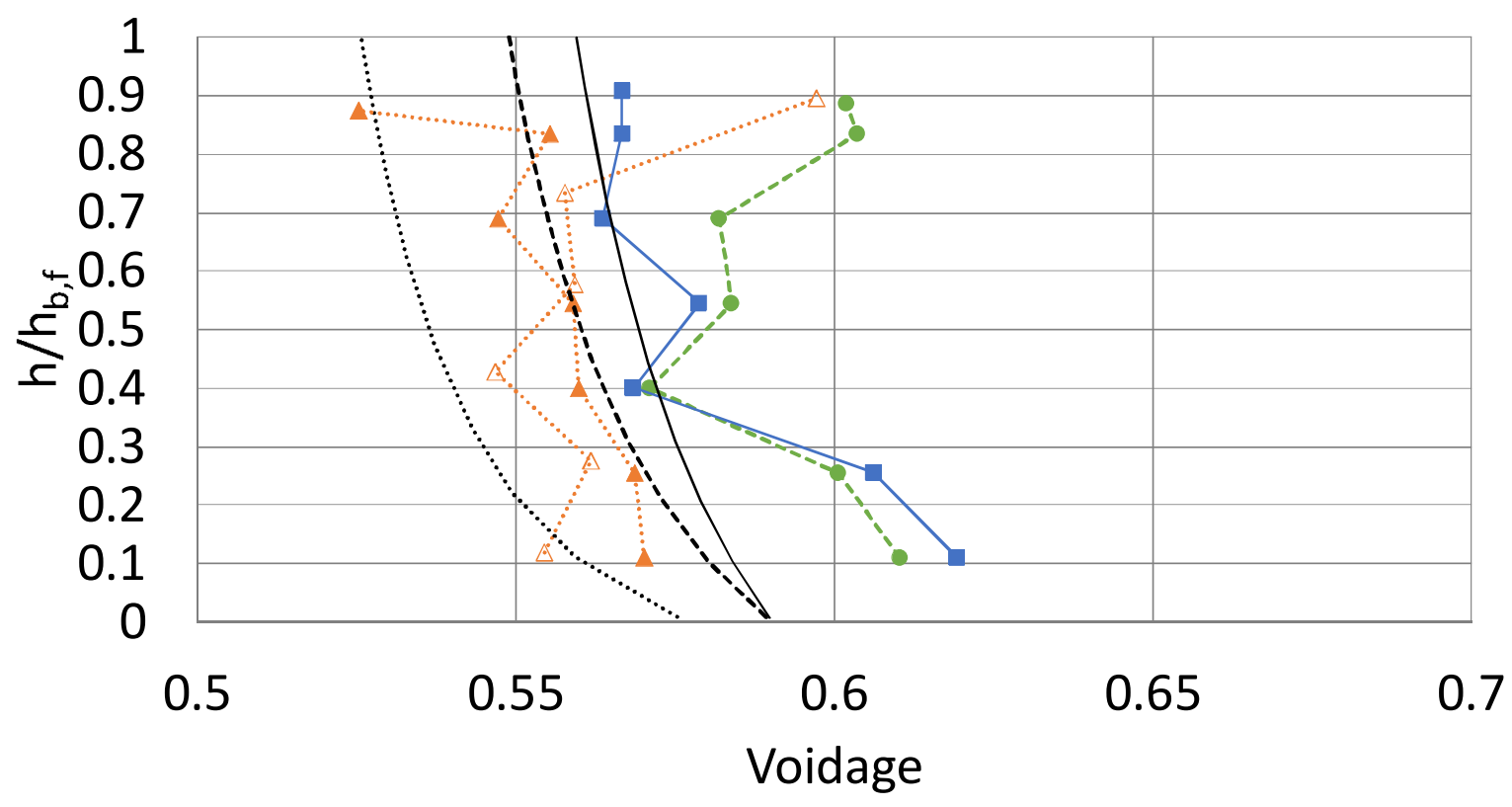

2.7 Umf, no wood $\quad$ …....2.7 Umf, model

....2.7 Umf, small chips balsa - $-5.04 \mathrm{Umf}$, small chips balsa

$-6.48 \mathrm{Umf}$, beech dowels $\quad----5.04 \mathrm{Umf}$, model

- $6.48 \mathrm{Umf}$, model 


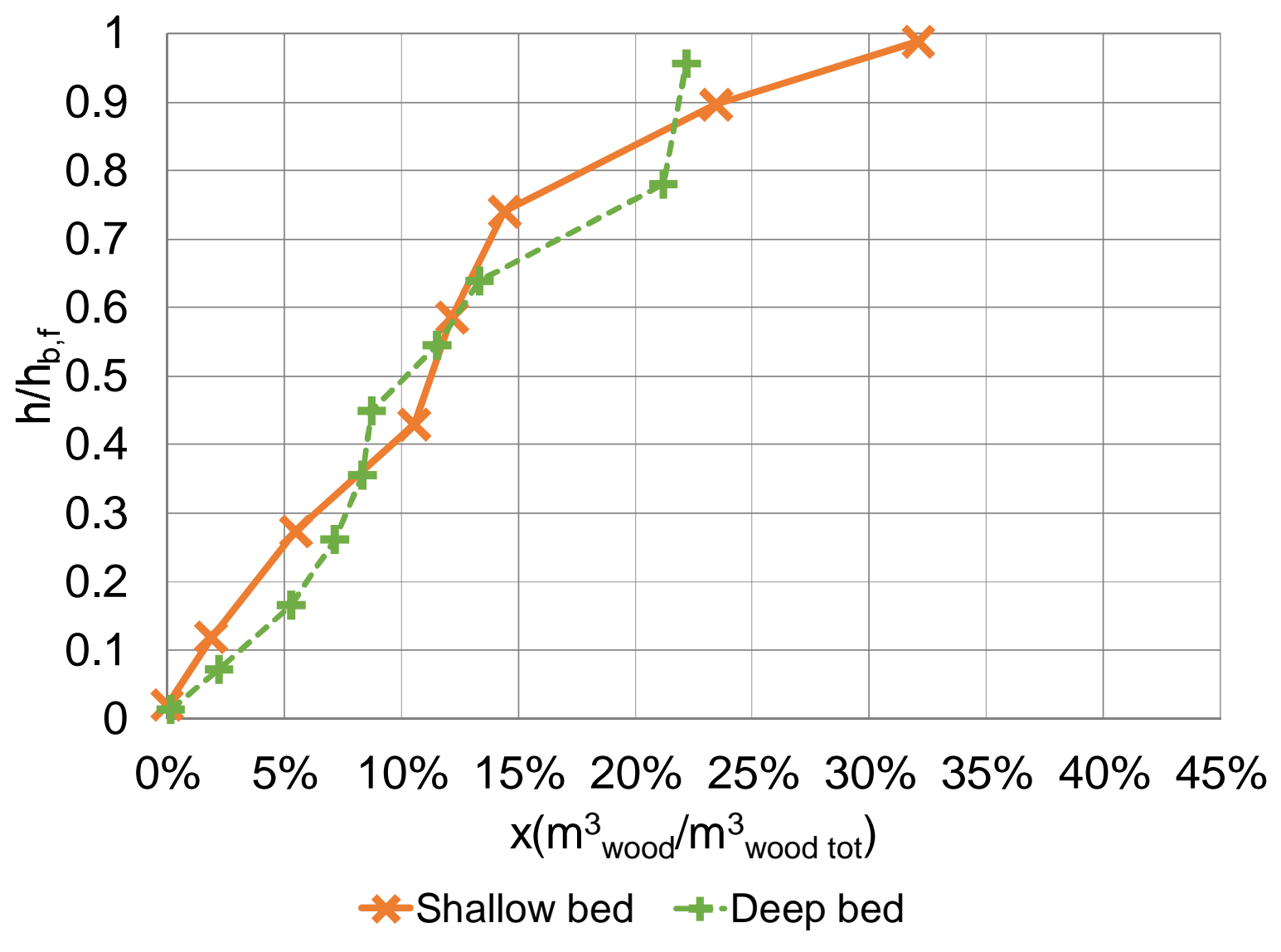




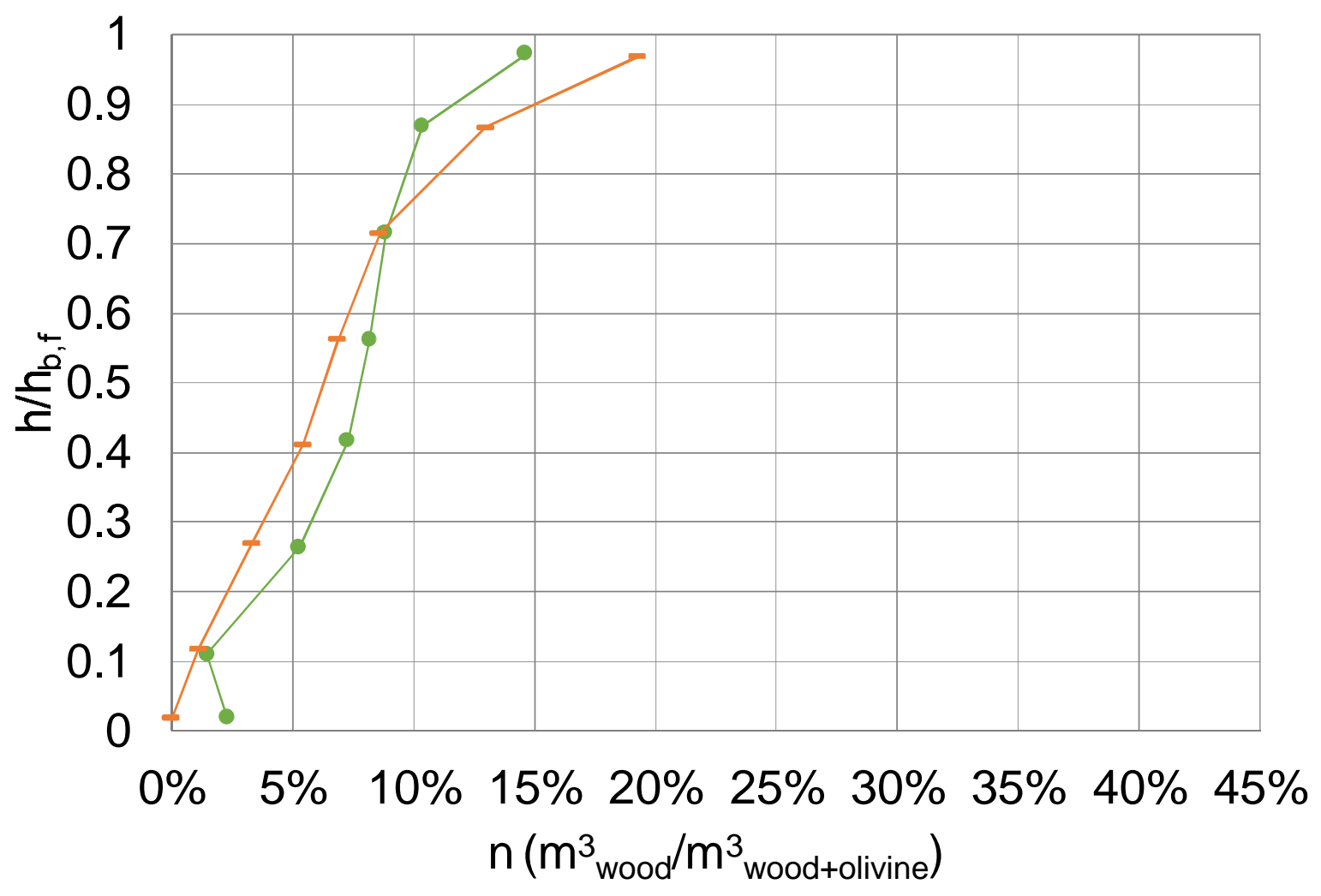

- -Beech chips --Beech dowels 


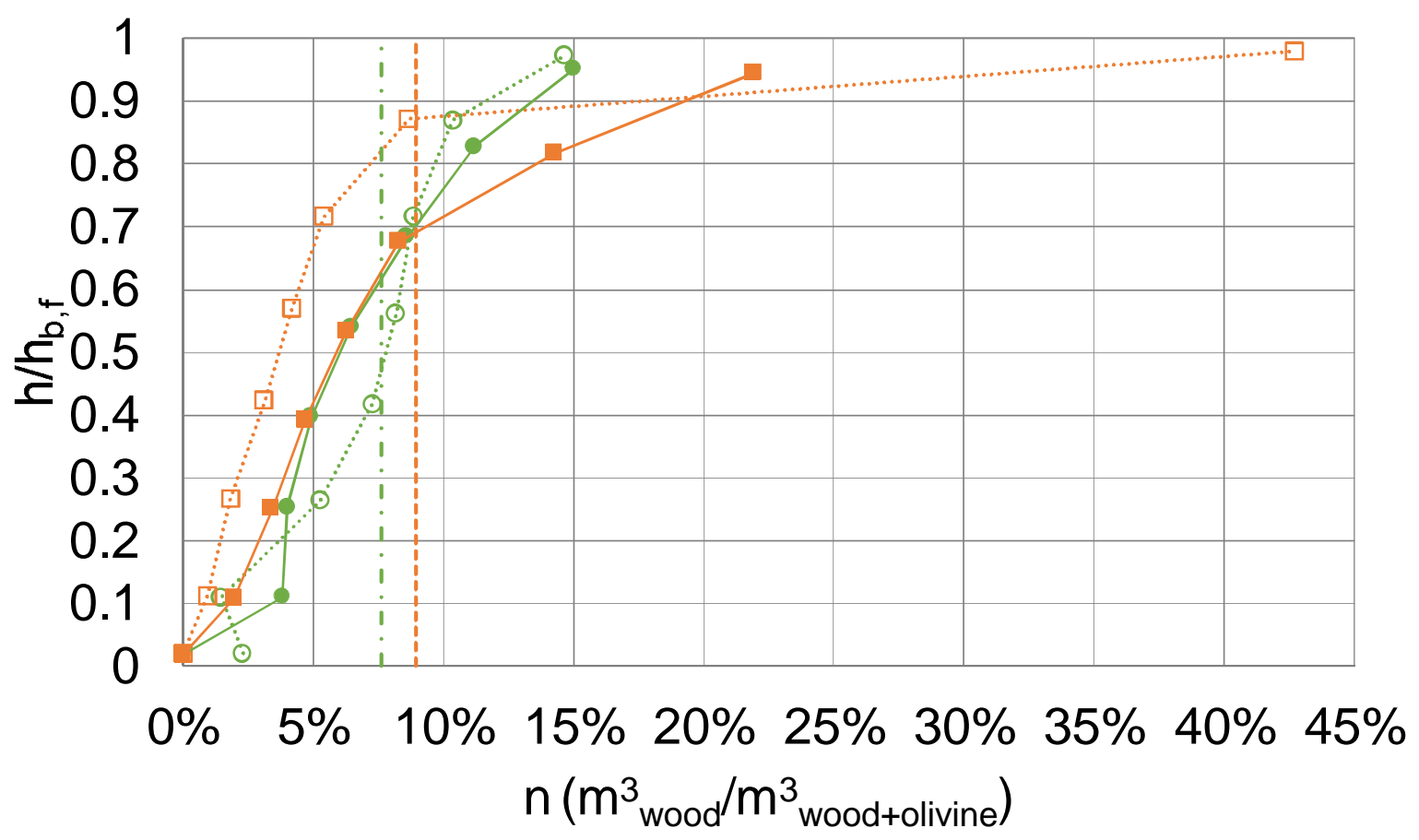

...2.15 Umf, beech chips

- $3.35 \mathrm{Umf}$, beech chips - $-3.35 \mathrm{Umf}$, balsa chips

-.-Well mixed beech ----Well mixed balsa 


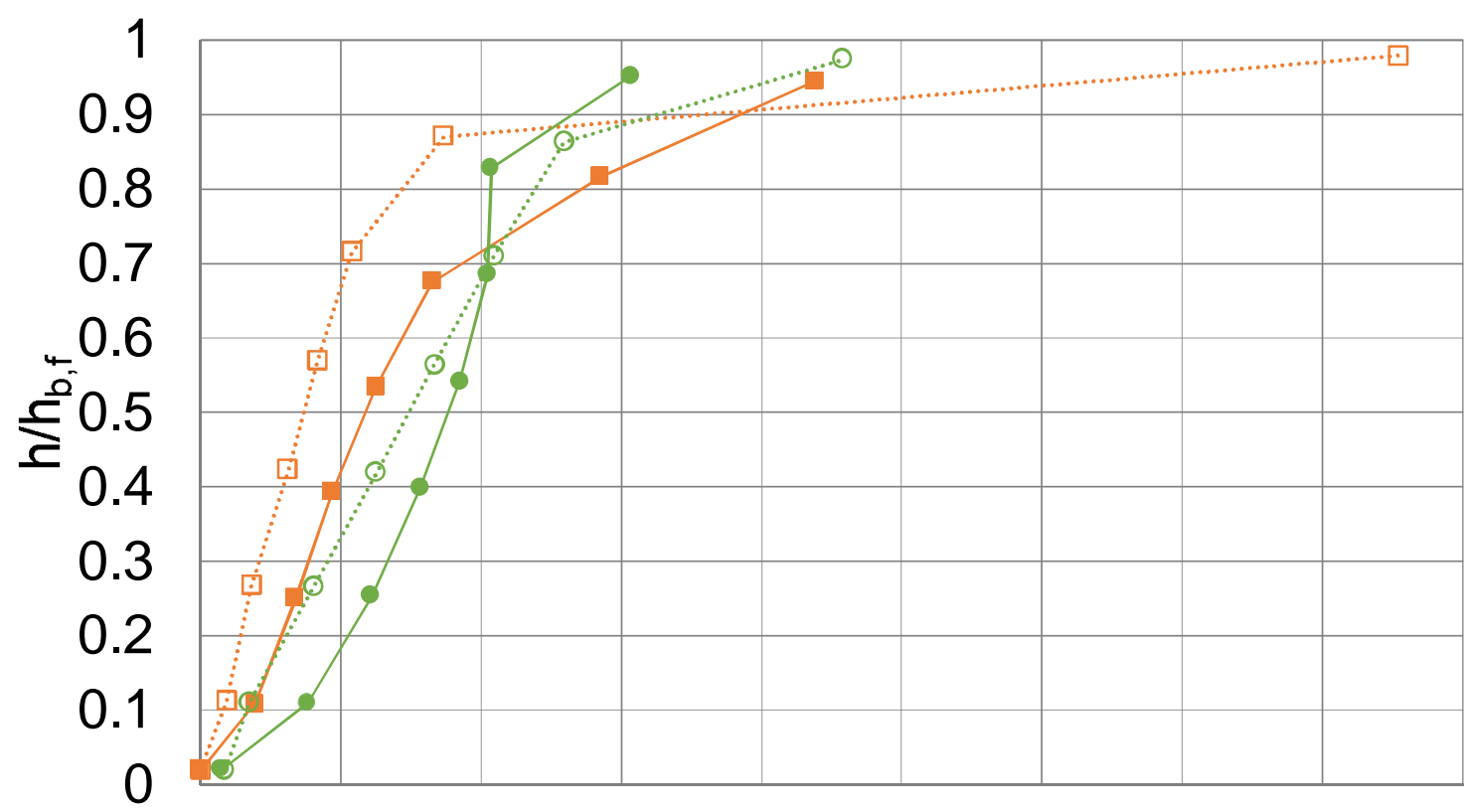

$\begin{array}{lllllllllll}0 \% & 5 \% & 10 \% & 15 \% & 20 \% & 25 \% & 30 \% & 35 \% & 40 \% & 45 \%\end{array}$ $\mathrm{n}\left(\mathrm{m}^{3}{ }_{\text {wood }} / \mathrm{m}^{3}\right.$ wood+olivine $)$

ख2.15 Umf, large chips - -3.35 Umf, large chips

๑..2.15 Umf, small chips -03.35 Umf, small chips 


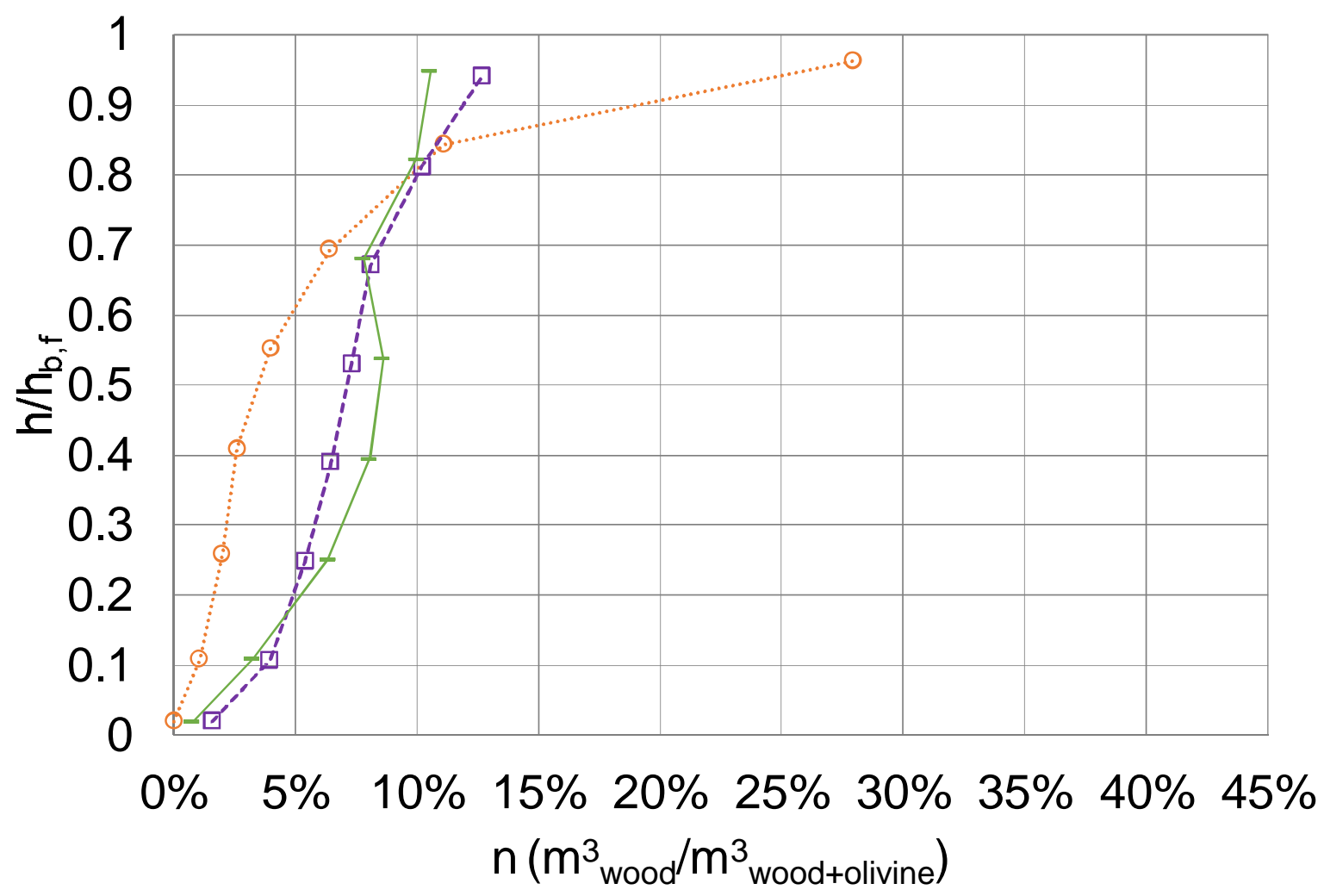

.๑. 2.7 Umf - - -5.04 Umf $\quad-6.48 \mathrm{Umf}$ 


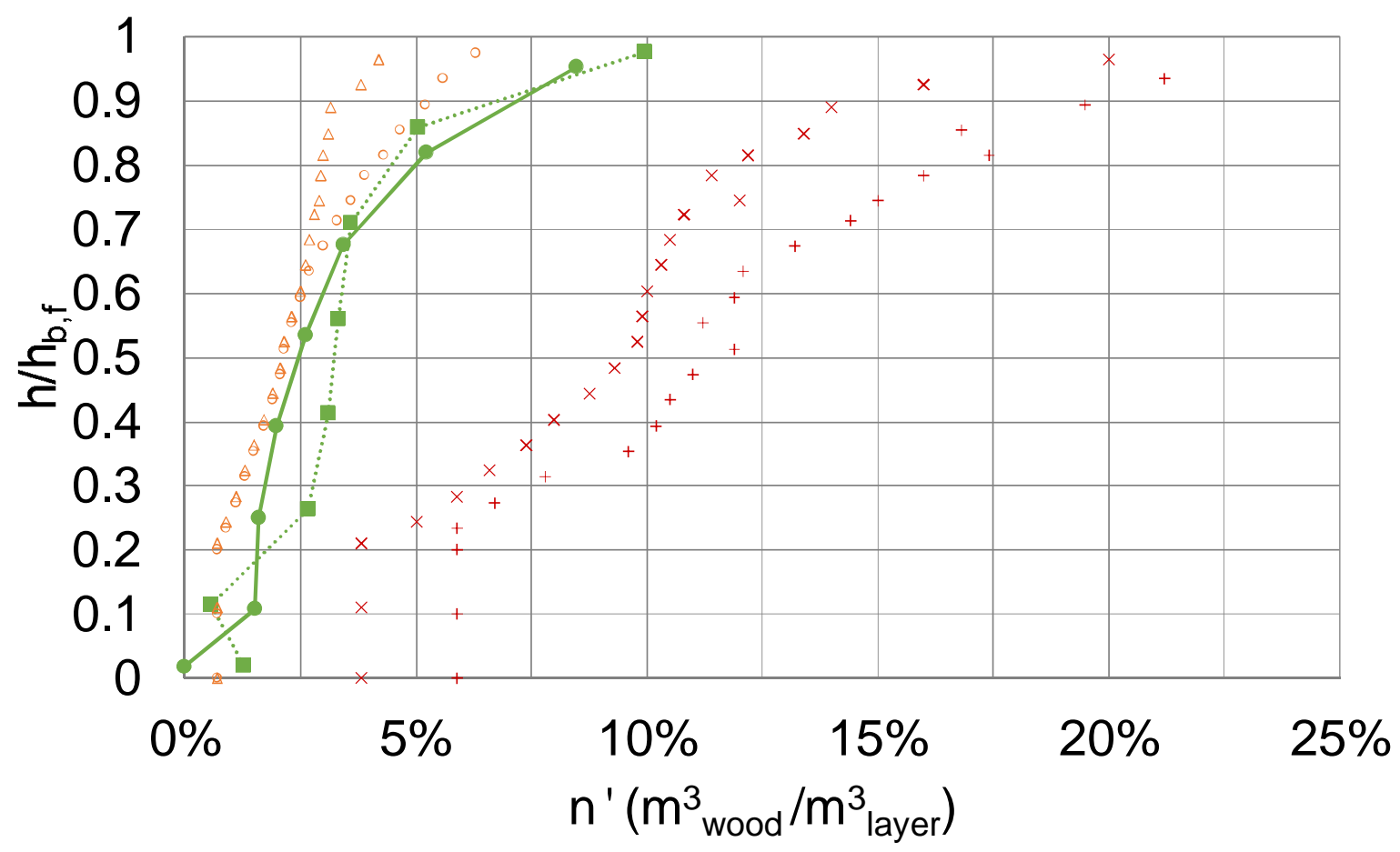

- 3.03 Umf Fotovat et al., $3.56 \%$ wood 5.38 Umf Fotovat et al., $3.56 \%$ wood

....2.15 Umf, $3.44 \%$ beech chips $\rightarrow-3.35 \mathrm{Umf}, 3.44 \%$ beech chips

+ 3.03 Umf Fotovat et al., $13.59 \%$ wood $\times 5.38$ Umf Fotovat et al., $13.59 \%$ wood 